\title{
EFFECT OF LAND USE CHANGES ON WATER RUN-OFF FROM A SMALL CATCHMENT IN THE CZECH REPUBLIC
}

\author{
PAVEL ONDR, JIŘÍ PEČENKA, JAKUB POLENSKÝ, JIŘÍ CIML
}

University of South Bohemia in České Budějovice, Faculty of Agriculture, Studentská 13, 37005 České Budějovice, Czech Republic; e-mail: moravcova.janca@seznam.cz

\begin{abstract}
Ondr P., Pečenka J., Polenský J., Ciml J.: Effect of land use changes on water run-off from a small catchment in the Czech Republic. Ekológia (Bratislava), Vol. 35, No. 1, p. 78-89, 2016.

The changes in the landscape during past years were affected mainly by political and financial conditions in the agricultural sector as well as the future changes probably will be. For this study various scenarios of changes in land use in the small catchment caused by human activity were simulated. Several scenarios were focused on changes of agricultural area to urbanized landscape and also on industrial use of several plots. The aim of this study was to model and assess the impact of human-induced landscape changes on run-off from small catchments in the traditional agricultural area. It can be said, that more than the change of land use itself, changed management of these areas affects the water run-off more. The hypothetical transfer of significant part of the catchment area or the localities with infiltration vulnerable zones into urbanized paved space is the only exception. This change mainly affects the rate of discharge.
\end{abstract}

Key words: SWAT, discharge, infiltration vulnerable zones, land use change, urbanization.

\section{Introduction}

The aim of this study was to model and assess the impact of human-induced landscape changes on run-off from small catchments in the traditional agricultural locality. As stated by Franczyk and Chang (2009) and Novaes Váchalová et al. (2010), the land use change is a very important factor affecting hydrological conditions of the catchment and mainly the run-off conditions. The same finding is confirmed also by Bernetti et al. (2006) and Du et al. (2013). Bulygina et al. (2009) or Jiang et al. (2011) showed that all landscapes are dramatically changed under the influence of various factors as demography, climate change, national policies and subsidies, economic conditions, among others.

Urbanization is one of the most significant changes of land use (Váchal et al., 2006, 2009a; Mihalč́ková et al., 2010). Currently, a significant trend of urban population is migration to safer locations nearby rural areas, where conditions are suitable for life, close to nature and offer an unspoiled environment (Louženská et al., 2011, Moravcová et al., 2013). For these new inhabitants of small villages near cities, mass construction of new houses occurs on the greenfield sites. Similar trend has been described through the whole world (e.g. Antrop 
(2004), Jayasinghe-Mudalige et al. (2007) or Pacione (2001)). At the same time, there is a need for the construction of new amenities such as kindergartens, etc. (Antrop, 2000). In some cases, there is also a full reorientation of traditional agriculture to other forms of economic activity, and thus it leads to the construction of commercial buildings, such as storage facilities, factories, solar power stations and so on (Pečenka et al., 2014). This phenomenon is well described mainly in post-Communist countries and countries in transition as documented by Sýkora and Ourednek (2007) or Moravcová et al. (2014) for the Czech Republic, by Timár and Váradi (2001) for Hungary, by Tosics (2004) or Raagmaa et al. (2009) for Baltic states.

As stated in Alig et al. (2004) and Chin (2006), globally the urban population increased in the last 40 years by $100 \%$ and the trend will continue for a minimum of the next 30 years. Such dramatic changes, according to Majid (2009), lead to radical changes in the hydrological behaviour of catchments (Hampicke, Roth, 2000). The regions are facing serious problems with water quality and also quantity (Lacroix et al., 2006, 2007; Martinez et al., 2007; Moravcová et al., 2009). The growth of impervious surface in urbanized catchments, according to Aronica and Cannarozzo (2000) and Zhou et al. (2013), leads to local decreases in infiltration, canopy interception and the water-holding ability (Spaziante, Murano, 2009). Consequently, there is a huge potential of flooding risk and also of water shortage. As showed by Dixon and Earls (2012) or Moravcová et al. (2014), this poses challenges to emergency and disaster management and planning efforts.

Brandmeyer and Karimi (2000) as well as Green et al. (2006) show that the hydrological and hydrochemical models have been serving for many years as an efficient tool for the planning of water resources management. Abu El-Nasr et al. (2005) describes these models as a simplified quantitative relationship between input and output parameters of a system. Simulations of these models are then used primarily to assess the impacts of the proposed scenarios in land use change and different water management strategies. Singh et al. (2005) considers the modelling of hydrological properties necessary for understanding processes in the catchments (Buzek et al., 2009). Arnold et al. (1998) adds that it is a necessary step to improve the management of the catchment. Also Heuvelmans et al. (2005) and Le Grusse et al. (2006) describe the modelling as the easiest way to determine the influence of natural factors and human factors on run-off and water quality (Brouwer et al., 2001). The application of such modelling approach can be confirmed by studies such as Guo et al. (2008), Palamuleni et al. (2011) or Ren et al. (2002).

Currently, according to Borah and Bera (2003), a wide range of hydrological models were developed, from which the most suitable simulation tool for the particular condition can be chosen. From these wide range of models, we have chosen the Soil and water assessment tool (SWAT). SWAT is a continuous model in scale catchment, which, in its basic version, works with a daily time step and is designed to predict the impact of management on the hydrology, sediment and chemicals associated with agricultural activities (Fohrer et al., 2005). The model is physically based and designed to work with long time series of continual monitoring. The main components of the model include weather, hydrology, soil science, plant growth, nutrients, pesticides and landscape management (Gassman et al., 2007). 


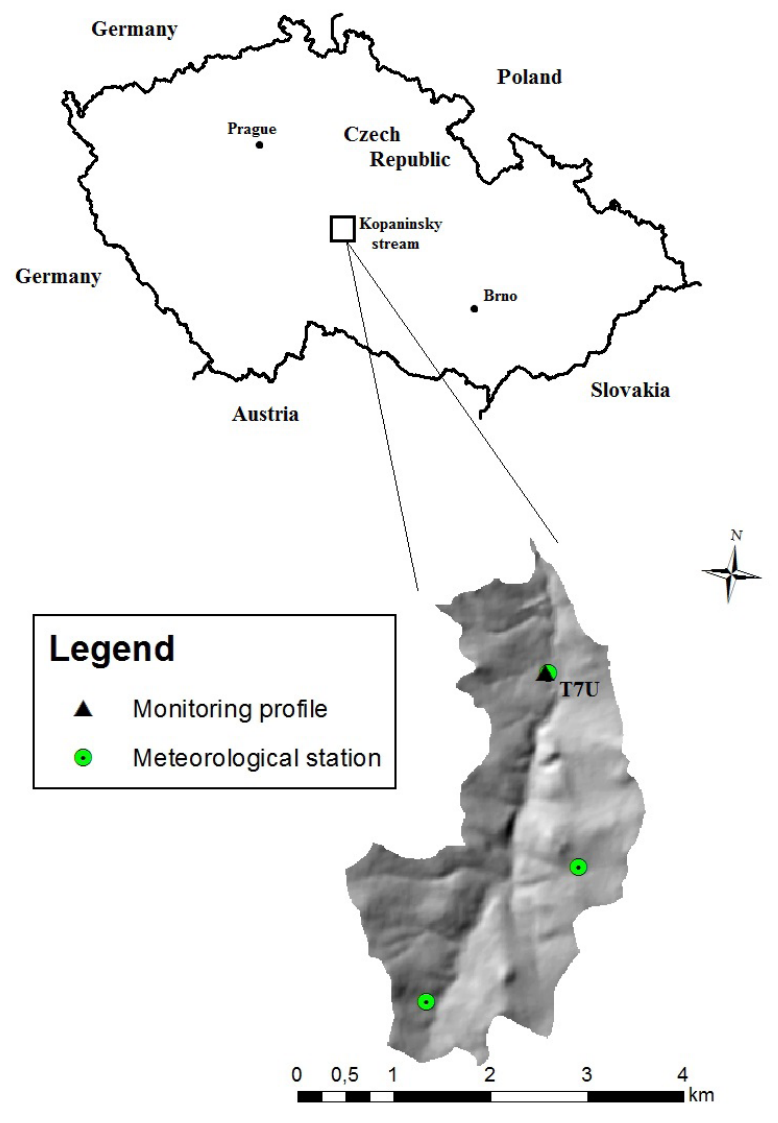

Fig. 1. Localization of Kopaninsky stream catchment in the Czech Republic.

\section{Material and methods}

\section{Material}

All activities associated with the preparation of the study were focused on Kopaninsky stream catchment. Kopaninsky stream catchment, covering $6.9 \mathrm{~km}^{2}$, is located in the central part of the Czech Republic (Fig. 1), Vysocina County, in the district Pelhrimov, cadastral areas Chvojnov, Kletecna u Humpolce, Onsovice u Dehtar, Velky Rybnik u Humpolce and Zirov.

The area lies at an altitude of 467-624 $\mathrm{m}$ above the sea level, the highest peak Pavlickuv kopec with an altitude $624 \mathrm{~m}$ above sea level is located in the south-western part of the catchment. The area is under the geomorphologic structure in the Czech Highlands province, subprovince of the Czech-Moravian system, the Bohemian-Moravian Highlands, Kremesnicka Highlands, Zelivska hills, Horepnicka hills. Bedrock consists of biotitic-muscovitic schist, Moldanubian mica schist with inter-layer of quartzite and quartritic gneisses. The most important soil types are Cambisol modal, Cambisol gleyed and modal, which cover most of the catchment area Kopaninsky stream. Kopaninsky stream catchment lies in the moderately warm climate. The Kopaninsky stream catchment is managed by more private farmers and agricultural companies. Agricultural area represents the type of potato-rye production area. Agricultural production is mostly based on the traditional method of agricultural production with application of traditional agro-technical practices.

Closing profile of this sub-catchment is equipped with a Thomson weir with a rectangular cut-out and is equipped with an ultrasonic device for continuous measurement and recording of flows and water levels. More detail desription of this catchment can be found in Kvítek et al. (2009, 2012).

\section{Methods}

For the modelling of runoff and the concentration of nitrate anions, semi-distributed model with continuous daily time step SWAT (Soil and Water Assessment Tool) designed for medium to large basins (Abbaspour et al., 2007; Arnold, Fohrer, 2005) was chosen. This is partially physically based model, which allows the simulation at a very high degree of spatial resolution by distribution of the catchment into a large number of small facets.

The basis of all operations in the SWAT model is a digital terrain model. In case of Kopaninsky stream catchment a total area of $6.9 \mathrm{~km}^{2}$ was divided into sub-catchments with an average area of $1.7 \mathrm{~km}^{2}$. The second spatial level is hydrological response unit HRU. Altogether the Kopaninsky stream catchment is defined by 87 HRUs with an average 
area of $0.05 \mathrm{~km}^{2}$. Hydrological cycle, as modelled in the SWAT, is based on the general water balance equation. The principal and most important components of the hydrological module of SWAT model are the values of surface run-off and evapotranspiration. Penman-Monteith method (Monteith, 1965) is used to calculate evapotranspiration. Meteorological characteristics of the basin provide moisture and energy inputs that determine the relative importance of different parts of the hydrological cycle. Variables that describe the weather in the river catchment model are daily rainfall, maximum and minimum air temperature, global radiation, wind speed and relative humidity. For this study, time series of daily rainfall totals of four rainfall stations were used. These are located on the Kopaninsky stream catchment, stations Velky Rybnik, U Turku and U Nemcu, and the nearby rain gauge station K4 located on the Dehtare catchment (Fig. 1). The distribution of individual soil units within the modelled area are used together with slope and land use for the purpose of defining the hydrological units HRUs. For the purposes of this study, there were used main soil units. For each pre-defined soil profile, the results obtained by the physical and chemical analyses of collected soil samples were added into the SWAT database. Database with descriptive characteristics of each type of land use is also integrated in the SWAT program. On the Kopaninsky stream catchment, five categories of land use, namely arable land, permanent grassland, forest, built-up area and water area were identified. The land included in the category of arable land was then described by cultivated crops based on field research in each year. This group includes crops such as winter wheat, spring barley, winter barley, winter oilseed rape, potatoes and corn. The required parameters of the physiology of plants were taken for each crop, but also for grassland and forest. The database connected to the SWAT model was completed by the database, which was compiled at the University of Giessen for a typical Central European and Western European crops (Breuer et al., 2003), and also by field measurements.

SWAT model for basin Kopaninsky flow was calibrated using a data series of discharges measured at the closure profile of Kopaninsky stream catchment marked T7U. To calibrate the discharges, time series of average daily discharge values from hydrological years 2009-2011 (1 November 2008 to 31 October 2011) were used. For subsequent validation, daily average discharge rates of the hydrological year 2012-2013 (1 November 2011 to 31 October 2013) were used. Calibration and validation involves comparing actual measured data series with the output of the model. Calibration was performed by automatic calibration module, which is also included in the module AvSWATX. Based on the sensitivity analysis of the LH-OAT (Latin Hypercube Sampling - One At A Time) (van Griensven et al., 2006), which is an integral part of the SWAT model, the most important calibration parameters were selected. For comparison, the conformity of the model with real measured data, three coefficients generally recommended for the evaluation of the models in the literature as Gassman et al. (2002) or van Griensven and Bauwens (2003) were used. This is the coefficient of determination, Nash-Sutcliff coefficient of predictions performance and the average error parameter.

\section{The modelled scenarios of different land use layout in the catchment}

All the following scenarios are shown in the Fig. 2. In the Kopaninsky stream catchment, arable land, which is intensively used for agriculture, is clearly dominant Arable land is conventionally used with crop rotation including both spring and winter variants of commonly cultivated cereals and root crops. This arrangement with the land use 
management has been identified as a baseline (Variant 0 ). Subsequently three possible alternative scenarios of land use were established, with a focus on human-induced changes. The scenarios are related to new built-up areas. Variant 1 assumed double expansion of built-up areas in the surrounding of present municipalities. Variant 2 assumed a four-fold expansion of built-up areas and the last Variant 3 described the hypothetical complete built-up of all infiltration vulnerable sites, according Janglová et al. (2003). In each scenario, the newly urbanized plots were simulated in five different variants according to the type of urbanization. The particular variants were defined according to the SWAT database with regard to fraction of impervious land and their connectivity. Each new variant was labelled by the letter A-E. The classification of the urbanized plots is summarized in Table 1.

T a b l e 1. Range and average impervious fractions for different urban land types (Neitsch et al., 2004).

\begin{tabular}{|c|l|c|c|}
\hline Variant & Urban land type & Average total impervious & Average connected impervious \\
\hline A & Residential - High density & 0.60 & 0.44 \\
\hline B & Residential - Medium density & 0.38 & 0.30 \\
\hline C & Residential - Low density & 0.12 & 0.10 \\
\hline D & Industrial & 0.84 & 0.79 \\
\hline E & Transportation & 0.98 & 0.95 \\
\hline
\end{tabular}

\section{Results and discussion}

Firstly, the SWAT model was calibrated and validated for the discharge rates. Different scenarios were subsequently inserted in the calibrated and verified model and finally their impact on the indicators of water quantity were evaluated.

\section{Calibration and validation of the model SWAT}

Since the SWAT model contains a large amount of descriptive parameters, there is the need to determine the parameters that are key from the perspective of the model calibration at first. For these purposes, SWAT model was firstly assembled to sensitivity analysis. Based on the results of integrated LH-OAT analysis, six calibration parameters were selected for discharge rates. Individual parameters, including the initial values, arelisted in Table 2.

It can be concluded that then chosen calibration parameters and methods are generally used to calibrate the discharges (van Griensven et al., 2002). The resulting values were adjusted according to the actual measurements, or the available relevant literature.

After adjustment for baseline values of the parameters mentioned above, the model was calibrated for discharge. The final comparison of data series measured at closure profile T7U during the hydrological year 2009-2010. Last recorded simulation characteristics gained after completion of the calibration of discharge are described in Table 3. Nash-Sutcliff coefficient value $\mathrm{E}=0.932$ is demonstrating the relatively good agreement between the simulated and measured discharge rate. The good agreement between data series is evidenced by the high value of the coefficient $R^{2}$, which after calibration reaches 0.944 . Nash-Sutcliff coefficient was mainly affected by inaccuracies in the simulation of discharge in the time of rainfallrun-off events and the short period that followed them closely. In these periods, the peak 
$\mathrm{T} \mathrm{a} \mathrm{b}$ le 2. Setting of the calibration parameters for the SWAT model for calibration of discharge in the Kopaninsky stream catchment $(\mathrm{T} 7 \mathrm{U})$.

\begin{tabular}{|c|c|c|c|c|}
\hline & \multicolumn{3}{|c|}{ Value } & \multirow{2}{*}{ Used method $\mathrm{g}$} \\
\hline & Minimal & Maximal & Final & \\
\hline GWQMIN a $^{\text {GW }}$ & -1000 & 1000 & -118 & 2 \\
\hline ALFA_BF ${ }^{b}$ & 0 & 1 & 0.35 & 1 \\
\hline ESCO $^{c}$ & 0 & 1 & 0.01 & 1 \\
\hline SOL_K ${ }^{d}$ & $-100 \%$ & $100 \%$ & $15 \%$ & 3 \\
\hline $\mathrm{CN}^{\mathrm{e}}$ & $-100 \%$ & $100 \%$ & $18 \%$ & 3 \\
\hline
\end{tabular}

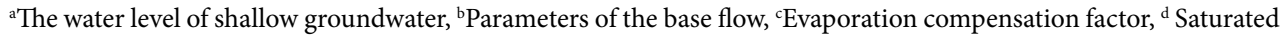
hydraulic conductivity, ${ }^{e}$ Run-off curve number; ${ }^{g} 1$. Change and replace the original parameter value by new. 2 . Gradual count up the constant correction factor to the initial value of the parameter; 3 . Multiplying the original value by the parameter correction factor generated as percentage of the original value.

discharges are typically overestimated. This fact is demonstrated especially in early spring rainfall-run-off episodes, when the discharge is overestimated by up to $25 \%$ compared to the measured value. The average value of the parameter errors ME is confirmation of these comparisons, which after calibration of the model reaches values of 0.012 , thus pointing to a slight overestimation of simulated data over the entire time period.

Periods, which closely follow the rainfall-run-off episodes, are in some cases the source of error in the discharge simulation, because of the unsatisfactory response of SWAT model for short-term reduction in discharge during recorded episodes, or episodes that follow each other in short sequences.

The calibrated model for Kopaninsky stream catchment was, before running the simulation of the proposed scenarios, tested on data from another time period.

${ }^{* * *}$ First, the discharge rate was chosen for verification. For the validation process, the data from hydrological year 2008 were used. The final statistical values characterizing the completed validation process for discharge are shown in Table 3 . Achieved final values are slightly lower than in the case of calibration. This confirms the generally known fact that the parameters that were specified for the model calibration period, not entirely cover the needs of the validation.

${ }^{* * *}$ The modelled values are almost for the entire period slightly overestimated, as evidenced by a positive coefficient ME. The biggest problem is the setting of calibration values that guarantee good agreement of discharges in periods with higher discharge rates. Again, it showed that the model incorrectly interprets the course of rainfall-run-off events that follow each other in rapid succession. Likewise, there are inaccuracies in the sudden drop in discharge during rainfall-run-off events, as it has already been shown in the process of calibration. 
Based on the results shown in Table 3, the results of calibration and validation process for discharge and concentrations of nitrate anions can be regarded as satisfactory and thus set model is suitable for solving the tasks set out in the aim of the study.

\section{Results of scenario simulations}

Gradually, increase of building area in the vicinity of existing small municipalities in the catchment twice and four times of the original size was simulated. In the last seventh simulated variant, hypothetical possibility of occupation of the arable land in the catchment was simulated. A similar trend was described in many countries around the world and similar study was described, for example, by Dixon and Earls (2012).

According to the results shown in Fig. 3, it is clear that all the three variants will lead even to a small increase in flow.

In the first simulated variant, the increase of flow is practically only very slight, only about $3.5 \%$. When doubling the area of present built-up areas, there will be no significant threat of flood in the village and the risk of significant damage during rainfall-runoff events should not even be increased. By comparing the particular variants of these scenarios all the simulated variants give approximately the same results in the range of $5.3 \%$. The best simulated variant from the point of view of discharge is low-density residential urban land. Similar conclusions were achieved by Majid (2009), who described the growth of flow of $2.5 \%$ by doubling the impervious localities in the watershed, or Koulová et al. (2011), Váchal et al. (2009b) and Franczyk and Chang (2009) who described the increase by $2.3-2.5 \%$ by doubling the urbanized landscape in the Rock Creek catchment in Oregon, USA. They also described the linear trend between the growth of urban land and discharge. Very similar results were also described by Brun and Band (2000) for Baltimore Metropolitan area where no significant change in outflow was recorded by $20 \%$ increase in urbanized impervious localities. Also Chang (2007) described very low increase in discharge (less than 2\%) in Pennsylvania catchment with change of land use from agricultural landscape to low density suburban landscape.

For the second simulated variant of four-fold increase in the paved areas, already a marked increase in average annual flow rates up to about $50 \%$ occurred. The most significant increase was recorded mainly in the values of peak flows during rainfall-run-off events. The increase in discharge rates was sometimes more than $100 \%$. In the simulation scenario 2 , individual variations are rather different.

The variance of individual values range between 126.3 and $162.7 \%$ of recorded flows. In this scenario, the two variants showed a significant variation. The first one recorded a higher increase of the flow at the development of medium-density than in high-density residential areas. The cause of the anomaly is especially significant in areas with wastewater sewer system, which draws water from the surface and therefore do not contribute to an increase in natural water run-off from the territory. The second abnormality compared with other simulations is lower simulated run-off from the land affected by transport infrastructure. The reason is again seen in the good drainage of wastewater from communications to a closed space (Ciml et al., 2015).

The risk of damage to property and the health of the population are therefore disproportionately increasing. The rapid increase in discharge mainly in downstream urbanized 


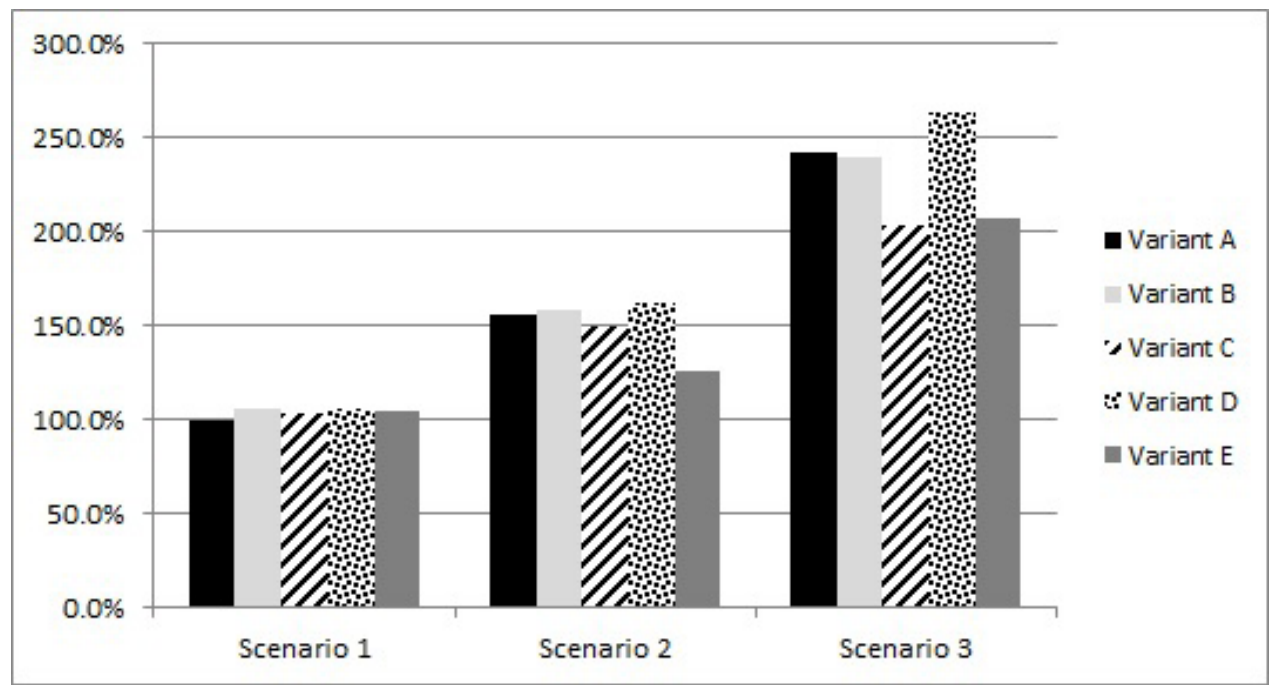

Fig. 3. Simulations results of different scenarios.

localities was described also by Petchprayoon et al. (2010) for catchments in Thailand and the results were supported also by study Niehoff et al. (2002) made in Germany or Koupilová et al. (2008) and Pavlíček et al. (2014) in the Czech Republic.

In the last scenario, the simulated complete building up of current arable land would report very alarming discharge rate. This option is only hypothetical, and its implementation cannot be expected, with the sole exception of the expansion of areas of solar power stations. In the case of implementation of this variant, the simulation of model SWAT showed the increase of discharges more than double of the current values. These results cannot be compared with any other studies because any author simulates such scenarios with the enlargement of the urbanized areas in similar conditions of infiltration vulnerable zones according to Janglová et al. (2003). In all variants of simulated flow This scenario shows the increase of over $200 \%$ of the original value. From Fig. 3, there is also an apparent fluctuation of the individual values from 203.4 to $263.2 \%$. Increase in flow variations with industrial land use is particularly alarming. A recorded increase in average annual flow rates has been up to $263.2 \%$. This scenario has become more important especially with a steady increase in the area of solar power plants. This trend is described also in Moravcová et al. (2008) or Váchal et al. (2010).

\section{Conclusion}

It can be said that more than the change of land use itself, changed management of these areas affects the water run-off more. The hypothetical transfer of a significant part of the catchment area or the localities with infiltration vulnerable zones into urbanized paved space is the only exception. This change mainly affects the rate of discharge. 
Completely building up of the whole catchment vulnerable zones was the worst variant, which would lead to almost doubling of the discharge and will lead to increasing of potential flood risk. This scenario is only hypothethical but it could be assumed that the present significant trend of urban population migration to safer locations of nearby rural areas, where conditions are suitable for life, close to nature and unspoiled environment, will lead to construction of new houses on greenfields. The pressure will be created to strengthen the weakened natural flood protection of the landscape mainly in localities vulnerable to infiltration of rainwater.

\section{References}

Abbaspour, K.C., Yang, J., Maximov, I., Siber, R., Bogner, K., Mieleitner, J., Zobrist, J. \& Srinivasan R. (2007). Modelling hydrology and water quality in the pre-alpine/alpine Thur watershed using SWAT. J. Hydrol., 333, 413-430. DOI: 10.1016/j.jhydrol.2006.09.014.

Abu El-Nasr, A., Arnold, J.G., Feyen, J. \& Berlamont J. (2005). Modelling the hydrology of a catchment using a distributed and a semi-distributed model. Hydrological Processes, 19, 573-587. DOI: 10.1002/hyp.5610.

Alig, R.J., Kline, J.D. \& Lichtenstein M. (2004). Urbanization on the US landscape: looking ahead in the 21st century. Landsc. Urban Plann., 69, 219-234. DOI: 10.1016/j.landurbplan.2003.07.004.

Antrop, M. (2000). Changing patterns in the urbanized countryside of Western Europe. Landsc. Ecol., 15, 257-270. DOI: $10.1023 / \mathrm{A}: 1008151109252$.

Antrop, M. (2004). Landscape change and the urbanization process in Europe. Landsc. Urban Plann., 67, 9-26. DOI: 10.1016/S0169-2046(03)00026-4.

Arnold, J.G., Srinivasan, R., Muttiah, R.S. \& Williams, J.R. (1998). Large area hydrologic modeling and assessment - Part 1: Model development. JAWRA Journal of the American Water Resources Association, 34, 73-89. DOI: 10.1111/j.1752-1688.1998.tb05961.x.

Arnold, J.G. \& Fohrer N. (2005). SWAT2000: current capabilities and research opportunities in applied watershed modelling. Hydrological Processes, 19, 563-572. DOI: 10.1002/hyp.5611.

Aronica, G. \& Cannarozzo M. (2000). Studying the hydrological response of urban catchments using a semi-distributed linear non-linear model. J. Hydrol., 238, 35-43. DOI: 10.1016/S0022-1694(00)00311-5.

Bernetti, I., Franciosi, C. \& Lombardi G.V. (2006). Land use change and the multifunctional role of agriculture: a spatial prediction model in an Italian rural area. Int. J. Agric. Res. Gov. Ecol., 5(2-3), 145-161. DOI: 10.1504/ IJARGE.2006.009161.

Borah, D.K. \& Bera M. (2003). Watershed-scale hydrologic and nonpoint-source pollution models: Review of mathematical bases. Transaction of ASAE, 46, 1553-1566. DOI: 10.13031/2013.15644.

Brandmeyer, J.E. \& Karimi H.A. (2000). Coupling methodologies for environmental models. Environmental Modelling \& Software, 15, 479-488. DOI: 10.1016/S1364-8152(00)00027-X.

Breuer, L., Eckhardt, K. \& Frede H.G. (2003). Plant parameter values for models in temperate climates. Ecol. Model., 169, 237-293. DOI: 10.1016/S0304-3800(03)00274-6.

Brouwer, F., Hellegers, P., Hoogeveen, M. \& Luesink H. (2001). Nitrogen pollution control in the European Union: challenging the requirements of the nitrates directive with the Agenda 2000 proposals. Int. J. Agric. Res. Gov. Ecol., 1(2), 136-144. DOI: 10.1504/IJARGE.2001.000006.

Brun, S. \& Band L. (2000). Simulating runoff behavior in an urbanizing watershed. Computers, Environment and Urban Systems, 24, 5-22. DOI: 10.1016/S0198-9715(99)00040-X.

Bulygina, N., McIntyre, N. \& Wheater H. (2009) Conditioning rainfall-runoff model parameters for ungauged catchments and land management impacts analysis. Hydrology and Earth System Sciences, 13, 893-904. DOI: 10.5194/hess-13-893-2009.

Buzek, F., Bystřický, V., Kadlecová, R., Kvítek, T., Ondr, P., Šanda, M., Zajíček, A. \& Žlábek P. (2009). Application of two-component model of drainage discharge to nitrate contamination. J. Contam. Hydrol., 106(3-4), 99-117. DOI: $10.1016 /$ j.jconhyd.2009.02.001.

Chang, H. (2007). Comparative streamflow characteristics in urbanizing basins in the Portland Metropolitan Area, Oregon, USA. Hydrological Processes, 21, 211-222. DOI: 10.1002/hyp.6233.

Chin, A. (2006). Urban transformation of river landscapes in a global context. Geomorphology, 79, 460-487. DOI: 
10.1016/j.geomorph.2006.06.033.

Ciml, J., Pečenka, J., Moravcová, J., Lechner, P. \& Kalíšek, J. (2015). Effect of land use on total phosphorus loss in selected locations. Acta Scientiarum Polonorum, Formatio Circumiectus, 14(1), 3-14.

Dixon, B. \& Earls J. (2012). Effects of urbanization on streamflow using SWAT with real and simulated meteorological data. Applied Geography, 35, 174-190. DOI: 10.1016/j.apgeog.2012.06.010.

Du, J., Rui, H., Zuo, T., Li, Q., Zheng, D., Chen, A., Xu, Y. \& Xu C.-Y. (2013). Hydrological simulation by SWAT model with fixed and varied parameterization approaches under land use change. Water Resources Management, 27, 2823-2838. DOI: 10.1007/s11269-013-0317-0.

Fohrer, N., Haverkamp, S. \& Frede H.G. (2005). Assessment of the effects of land use patterns on hydrologic landscape functions: development of sustainable land use concepts for low mountain range areas. Hydrological Processes, 19, 659-672. DOI: 10.1002/hyp.5623.

Franczyk, J. \& Chang H. (2009). The effects of climate change and urbanization on the runoff of the Rock Creek basin in the Portland metropolitan area, Oregon, USA. Hydrological Processes, 23, 805-815. DOI: 10.1002/ hyp.7176.

Gassman, P.W., Osei, E., Saleh, A. \& Hauck L.M. (2002). Application of an environmental and economic modeling systém for watershed assessments. JAWRA Journal of the American Water Resources Association, 38, 423-438. DOI: $10.1111 /$ j.1752-1688.2002.tb04327.x.

Gassman, P.W., Reyes, M.R., Green, C.H. \& Arnold J.G. (2007). The soil and water assessment tool: Historical development, applications, and future research directions. Transactions of the Asabe, 50, 1211-1250. DOI: 10.13031/2013.23637.

Green, C.H., Tomer, M.D., Di Luzio, M. \& Arnold J.G. (2006). Hydrologic evaluation of The Soil and Water Assessment Tool for a large tile-drained watershed in Iowa. Transactions of the Asabe, 49, 413-422. DOI: 10.13031/2013.20415.

Guo, H., Hu, Q. \& Jiang T. (2008). Annual and seasonal streamflow responses to climate and land-cover changes in the Poyang Lake basin, China. J. Hydrol., 355, 106-122. DOI: 10.1016/j.jhydrol.2008.03.020.

Hampicke, U. \& Roth D. (2000). Costs of land use for conservation in Central Europe and future agricultural policy. Int. J. Agric. Res. Gov. Ecol., 1(1), 95-108. DOI: 10.1504/IJARGE.2000.006913.

Heuvelmans, G., Garcia-Qujano, J.F., Muys, B., Feyen, J. \& Coppin P. (2005). Modelling the water balance with SWAT as part of the land use impact evaluation in a life cycle study of $\mathrm{CO}_{2}$ emission reduction scenarios. $\mathrm{Hy}$ drological Processes, 19, 729-748. DOI: 10.1002/hyp.5620.

Janglová, R., Kvítek, T. \& Novák P. (2003) Categorization of soil infiltration capacity based on GIS processing of soil survey data. Soil and Water, 2, 61-81.

Jayasinghe-Mudauoge, U., Weersink, A., Deaton, B. J. \& Trant M. (2007). Effect of urbanisation on the adoption of environmental management systems in Canadian agriculture. Int. J. Agric. Res. Gov. Ecol., 6(3), 316-325. DOI: 10.1504/IJARGE.2007.012839.

Jiang, S., Ren, L., Yong, B., Singh, V.P., Yang, X. \& Yuan F. (2011). Quantifying the effects of climate variability and human activities on runoff from the Laohahe basin in northern China using three different methods. Hydrological Processes, 25, 2492-2505. DOI: 10.1002/hyp.8002.

Koulová, L., Koupilová, M., Moravcová, J. \& Váchal J. (2011). Zhodnocení KPÚ Horní Stropnice z hlediska protierozní ochrany. Littera Scripta, 4(2), 193-201.

Koupilová, M., Moravcová, J., Váchal, J., Váchalová, R., Pártlová, P., Krejča, M., Šír, M., Straková, J. \& Mika K. (2008). Změny zemědělského půdního fondu a krajinné matrice v podhorských oblastech. Littera Scripta, 1(2), 137-145.

Kvítek, T., Žlábek, P., Bystřický, V., Fučík, P., Lexa, M., Gergel, J., Novák, P. \& Ondr P. (2009). Changes of nitrate concentrations in surface waters influenced by land use in the crystalline complex of the Czech Republic. Physics and Chemistry of the Earth, 34(8-9), 541-551. DOI: 10.1016/j.pce.2008.07.003.

Kvítek, T., Bystřický, V., Peterková, J., Žlábek, P. \& Moravcová J. (2012). Dynamika koncentrací a interakce odnosu dusičnanů a fosforu na malých zemědělsko-lesních subpovodích v povodí VN Švihov na Želivce. Vodní Hospodářství, 62(6), 198-203.

Lacroix, A., Laurent, F., Ruelland, D. \& Sauboua E. (2006). Nitrate pollution risk assessment: from the model to the indicator. Int. J. Agric. Res. Gov. Ecol., 5(2-3), 206-223. DOI: 10.1504/IJARGE.2006.009164.

Lacroix, A., Bel, F., Mollard, A. \& Sauboua E. (2007). Interest of site-specific pollution control policies: the case of nitrate pollution from agriculture. Int. J. Agric. Res. Gov. Ecol., 6(1), 45-59. DOI: 10.1504/IJARGE.2007.012142.

Le Grusse, P., Belhouchette, H., Le Bars, M., Carmona, G. \& Attonaty J. (2006). Participative modelling to help col- 
lective decision-making in water allocation and nitrogen pollution: application to the case of the Aveyron-Lere Basin. Int. J. Agric. Res. Gov. Ecol., 5(2-3), 247-271. DOI: 10.1504/IJARGE.2006.009166.

Louženská, I., Moravcová, J., Koupilová, M., Pavlíček, T. \& Váchal J. (2011). Zhodnocení problémů rozvoje malých obcí - př́ípadová studie Záblatí. Littera Scripta, 4(1), 165-179.

Majid, M.R. (2009). Simulating impacts of residential patterns on hydrology of an urbanizing watershed by using SWAT and ArcView GIS. http://www.gisdevelopment.net/application/nrm/water/overview/mm025pf.htm.

Martinez, Y., Calvo, E. \& Albiac J. (2007). A dynamic analysis of nonpoint pollution control instruments in agriculture. Int. J. Agric. Res. Gov. Ecol., 6(1), 60-78. DOI: 10.1504/IJARGE.2007.012143.

Mihalčíková, Z., Koupilová, M., Moravcová, J., Ondr, P. \& Váchal J. (2010). Historická geneze krajiny v podhorských oblastech - př́ípadová studie katastrálního území Zdíkov. Littera Scripta, 3(1-2), 214-233.

Monteith, J. (1965). Evaporation and environment. In The state and movement of water in living organisms (pp. 205-224).19th Symposium of the Society for Experimental Biology. Cambridge: Cambridge University Press.

Moravcová, J., Koupilová, M., Váchal, J., Váchalová, R., Pártlová, P., Krejča, M., Šír, M. \& Straková J. (2008). Vliv zemědělského využití území na jakost vody v důsledku extrémních srážko-odtokových jevů. Littera Scripta, 1(2), 147-160.

Moravcová, J., Pavlíček, T., Koupilová, M., Ondr, P., Váchalová, R. \& Váchal J. (2009). Behavior of selected c-q hysteresis parameters by extreme rainfall-runoff events in artificially drained localities. Journal of Landscape Studies, 2(3-4), 77-88. www.centrumprokrajinu.cz/jls/

Moravcová, J., Pavlíček, T. \& Ondr, P. (2013). Effect of land use changes on water runoff and nutrients loss from a small catchment in the Czech Republic. 8th Conference on Sustainable development of energy, water, and environment systems (pp. 300:1-300:14), Conference proceedings, Vol. 8. Zagreb.

Moravcová, J., Pavlíček, T. \& Ondr, P. (2014). Is the historical land use arrangement the key to lower flood risk and better water quality?. 9th Conference on Sustainable development of energy, water, and environment systems (pp. 275-285), Conference proceedings, Vol. 9. Zagreb.

Moravcová, J., Pavlíček, T., Ondr, P. \& Pečenka J. (2014). Development of land use and land tenure in relation to the historical socio-political changes in the Central Europe - case study Czech-Austrian border. In GeoConference on Ecology, Economics, Education and Legislation (pp. 103-112). Conference proceedings, Vol. 3. Sofia: STEF92 Technology Ltd.

Neitsch, S., Arnold, J., Kiniry, J., Srinivasan, R. \& Williams J. (2004). Soil and water assessment tool input/output file documentation version 2005. Grassland. Soil and Water Research Laboratory, Agricultural Research Service, Blackland Research Center, Texas Agricultural Experiment Station.

Niehoff, D., Fritsch, U. \& Bronstert A. (2002). Land-use impacts on storm-runoff generation: scenarios of land-use change and simulation of hydrological response in a meso-scale catchment in SW-Germany. J. Hydrol., 267, 80-93. DOI: 10.1016/S0022-1694(02)00142-7.

Novaes Váchalová, R., Ondr, P., Moravcová, J., Koupilová, M., Váchal, J., Pártlová, P. \& Dumbrovský M. (2010). Landscape potential assessment - a prerequisite for regional development. Journal of Landscape Studies, 3(4), 237-245.

Pacione, M. (2001). Models of urban land use structure in cities of the developed world. Geography, 86, 97-119.

Palamuleni, L.G., Ndomba, P.M. \& Annegarn H.J. (2011). Evaluating land cover change and its impact on hydrological regime in Upper Shire river catchment, Malawi. Regional Environmental Change, 11, 845-855. DOI: 10.1007/s10113-011-0220-2.

Pavlíček, T., Moravcová, J., Ondr, P. \& Ciml J. (2014). Comparison of the nitrate concentration changes in relation to the different formation of flood curves on the grassy catchment during rainfall-runoff. In GeoConference on Water Resources, Forest, Marine and Ocean Ecosystems (pp. 151-159). Conference proceedings, Vol. 1. Sofia: STEF92 Technology Ltd.

Pečenka, J., Ondr, P. \& Moravcová, J. (2014). Analysis of the causes of land use changes in the Czech Republic in different production condition?. 9th Conference on Sustainable development of energy, water, and environment systems (pp. 367-374), Conference proceedings, Vol. 9. Zagreb.

Petchprayoon, P., Blanken, P.D., Ekkawatpanit, C. \& Hussein K. (2010). Hydrological impacts of land use/land cover change in a large river basin in central-northern Thailand. International Journal of Climatology, 30, 1917-1930. DOI: $10.1002 /$ joc. 2131 .

Raagmaa, G., Trasberg, V., Burneika, D. \& Krisjane Z. (2009). Rural restructuring and local/regional governance in the Baltic States after 1990. Int. J. Agric. Res. Gov. Ecol., 8(2-4), 180-204. DOI: 10.1504/IJARGE.2009.026225.

Ren, L., Wang, M., Li, C. \& Zhang W. (2002). Impacts of human activity on river runoff in the northern area of 
China. J. Hydrol., 261, 204-217. DOI: 10.1016/S0022-1694(02)00008-2.

Singh, J., Knapp, H.V., Arnold, J.G. \& Demissie M. (2005). Hydrological modeling of the iroquois river watershed using HSPF and SWAT. JAWRA Journal of the American Water Resources Association, 41, 343-360. DOI: 10.1111/ j.1752-1688.2005.tb03740.x.

Spaziante, A. \& Murano C. (2009). Rural development programmes and strategic environmental assessment: towards a sustainable rural territory. Int. J. Agric. Res. Gov. Ecol., 8(2-4), 205-222. DOI: 10.1504/IJARGE.2009.026226.

Sýkora, L. \& Ourednek M. (2007). Sprawling post-communist metropolis: commercial and residential suburbanization in Prague and Brno, the Czech Republic. Employment Deconcentration in European Metropolitan Areas, 91, 209-233. DOI: 10.1007/978-1-4020-5762-5 8.

Timár, J. \& Váradi M.M. (2001). The uneven development of suburbanization during transition in Hungary. European Urban and Regional Studies, 8, 349-360. DOI: 10.1177/096977640100800407.

Tosics, I. (2004). European urban development: Sustainability and the role of housing. Journal of Housing and the Built Environment, 19, 67-90. DOI: 10.1023/B:JOHO.0000017707.53782.90.

Váchal, J., Mazín, V., Trantinová, M., Novaes Váchalová, R., Moravcová, J. \& Koupilová M. (2010). Změny struktury krajiny vlivem pozemkových úprav. Littera Scripta, 3(1-2), 350-376.

Váchal, J., Váchalová, R., Vlčková, Z., Moravcová, J. \& Koupilová M. (2006). Anthropoecological zoning of farmland as a basis for land adjustment projection. Ekológia (Bratislava), 25(3), 144-161.

Váchal, J., Straková, J., Moravcová, J. \& Koupilová M. (2009a). Typology and landscape structuralization. Littera Scripta, 2, 161-180.

Váchal, J., Škoda, S., Popp, F., Váchalová, R., Moravcová, J. \& Koupilová M. (2009b). The Hluboká tectonic break - a significant geofactor of Hluboká nad Vltavou. Journal of Landscape Studies, 2(3-4), 89-95.

van Griensven, A., Francos, A. \& Bauwens W. (2002). Sensitivity analysis and auto-calibration of an integral dynamic model for river water quality. Water Sci. Technol., 45(9), 325-332.

van Griensven, A. \& Bauwens W. (2003). Concepts for river water quality processes for an integrated river basin modelling. Water Sci. Technol., 48, 1-8.

van Griensven, A., Breuer, L., Di Luzio, M., Vandenberghe, V., Goethals, P., Meixner, T., Arnold, J. \& Srinivasan R. (2006). Environmental and ecological hydroinformatics to support the implementation of the European Water Framework Directive for river basin management. Journal of Hydroinformatics, 8, 239-252. DOI: 10.2166/ hydro.2006.010.

Zhou, F., Xu, Y., Chen, Y., Xu, C.-Y., Gao, Y. \& Du J. (2013). Hydrological response to urbanization at different spatiotemporal scales simulated by coupling of CLUE-S and the SWAT model in the Yangtze River Delta region. J. Hydrol., 485,113-125. DOI: 10.1016/j.jhydrol.2012.12.040. 